Ryan, Curtis R. (1998) Peace, bread and riots: Jordan and the international monetary fund.

Middle East Policy 6:2 (October 1998), p. 54-66. Published by Wiley-Blackwell. The definitive version is available at www3.interscience.wiley.com]. DOI: 10.1111/j.1475-4967.1998.tb00308.x

\title{
Peace, Bread and Riots: Jordan and The International Monetary Fund
}

\author{
Curtis R. Ryan
}

\begin{abstract}
ARTICLE
For most indebted countries in the Middle East and throughout the "Third World", a recurring theme is that of economic adjustment and liberalization, often at the behest of the dominant economic and financial institutions of the global political economy. From a political perspective what is most interesting, and most troubling, about economic adjustment programs is their frequent correlation with political instability and unrest. For that reason, the International Monetary Fund (IMF) has long remained one of the most controversial institutions on the world stage. To some governments, it represents a key source of financial survival, to others a hated and powerful economic overseer akin to a thuggish loan shark. It is the latter more pejorative image of the IMF that seems to resonate more clearly with the general public throughout Africa, Latin America, Asia and the Middle East. This negative image is certainly due in large part to the social and political costs associated with economic adjustment. And the Jordanian experience with IMF austerity and adjustment programs has done nothing to soften that image.
\end{abstract}

In April 1989, the Jordanian government implemented an IMF-sponsored economic-adjustment and austerity plan, which had violent results. Riots erupted and then spread across the country. Seven years later, in August 1996, the Jordanian government once again complied with IMF guidelines, leading to another political upheaval. While the two incidents appear identical in terms of government policy and public response, they differ considerably in terms of the state's reaction to the unrest. In 1989 the Hashemite regime scrambled to make concessions, but in the 
more recent instability the king stood behind the government, offered no concessions and, to the contrary, threatened to use any means necessary to quell the disturbances.

This paper analyzes the connections between economic adjustment and political instability in the Jordanian context, with particular emphasis on the startling differences in Hashemite regime responses to the upheavals of 1989 and 1996.(1) Drawing on field research and interviews with Jordanian policy makers (conducted in 1992, 1993 and 1997), I argue that the key difference is that Jordan has undergone a wholesale domestic and international realignment since 1989 . The 1989 and 1996 austerity measures, in short, are part of the same broad program of economic and even political restructuring in Jordan since the late eighties. But since this is a cumulative process of political as well as economic adjustment, the domestic and international circumstances for the regime had changed considerably between 1989 and 1996. Economicadjustment measures, therefore, must be seen as intricately linked to Jordan's domestic political changes as well as to its foreign-policy shifts (including peace with Israel). Taken together, these policies are intended to ensure the long-term survival of the Hashemite regime in a postCold War, post-Gulf War, and even post-King Hussein world. It is the very success of this comprehensive "realignment" process, then, that explains the different government reactions to unrest in 1989 and 1996.

\section{ECONOMIC ADJUSTMENT AND POLITICAL UNREST, 1989}

Although Jordan's 1989 austerity program was implemented in April of that year, the roots of the policy may be found earlier in the 1970s and 1980s in Jordan's incorporation into the regional political economy of oil. Following the first oil shock in 1973, the regional petroleum economy had boomed, yielding ample opportunities for small states like Jordan to have access to Gulf labor markets and sources of foreign aid. But when the regional economy began to contract in the 1980s, the net result for Jordan was a decline in labor remittances and in Arab foreign aid financed through petrodollars. Jordan's economy has, for the kingdom's entire history, been dependent on various sources of foreign aid, including that from the United Kingdom and later from the United States.(2) But the oil revolution that transformed the regional political economy affected Jordan too. Although not an oil producer itself, Jordan had become increasingly dependent on the regional political economy of oil by virtue of its main export: people. Palestinian and Jordanian workers flocked to the Gulf states to work the oil fields as skilled laborers and to fill key professional positions from engineers to bankers to teachers. The kingdom came to rely more and more on these Gulf connections as a source of Jordanian employment, labor remittances, and considerable Arab foreign aid to Jordan as a frontline state in the conflict with Israel. At the 1978 Baghdad summit of the Arab League, for example, wealthy Arab states promised to extend far more aid to Jordan, largely to ensure that the kingdom would not follow Egyptian President Anwar Sadat's lead in signing a separate peace 
with Israel.(3) Jordan may not have had peace, but the regime and to some extent the society benefited from the oil boom of the 1970s and hoped it would continue into the 1980s.

But as the eighties began, the global economy was still reeling from the effects of the oil shock that followed the Iranian Revolution in 1979 and the onset of the Iran-Iraq War the following year. This economic jolt, combined with global changes in oil markets, signaled the beginning of a contraction of the oil economy. For Jordan, this resulted not only in declining labor remittances, but also in a decline in Arab bilateral aid, just as the kingdom's economic planners had established higher levels of government spending.(4) With increasing shortfalls in the national budget throughout the 1980s, Jordan resorted to more and more external borrowing. As remittances and aid declined, the national debt steadily rose. By 1988, Jordan's debt was twice its Gross Domestic Product (GDP).

Some early halting attempts at minor economic restructuring had begun by the mid-eighties, but it was not until March of 1989 that the government of Prime Minister Zayd al-Rifaai felt compelled to turn to the IMF and the World Bank to renegotiate and reschedule Jordan's debt payments.(5) The depth of the economic crisis became clear as Jordan stopped making payments on bilateral government loans. This emergency economic measure was announced in March; the regime had no choice but to seek new terms for its debt repayments. IMF assistance, however, does not come without strings attached, in this case a five-year plan for economic adjustment and stabilization. In return, the IMF agreed to grant Jordan $\$ 125$ million in credit in addition to more than $\$ 100$ million in loan money to come from the World Bank over a two-year period. The IMF's main concern was with Jordan's enormous budget deficit. The austerity plan, therefore, included in its key provisions steps to cut government expenditures as dramatically as possible.(6)

While Jordan's raw economic indicators make clear the regime's increasingly dire economic position, a number of other factors are also worthy of note. To some extent, the economic constraints themselves helped compel the regime to make some significant foreign-policy adjustments, spurred on by developments beyond the kingdom itself. In 1987, for example, the West Bank and Gaza Strip exploded into active resistance against Israeli occupation in what came to be known as the intifada. As the violence and unrest in the occupied territories continued, King Hussein finally acceded to the policy recommendations of many top Jordanian policy makers by formally renouncing the monarchy's claims to the West Bank. At least some of the those who urged the king to sever the West Bank ties argued that such a move was necessary to allow the regime to focus on political consolidation and economic renewal in what they viewed as "Jordan proper".(7) 
In 1989, Jordan also announced the formation of a new Arab political alignment and economic bloc -- the Arab Cooperation Council (majlis al-taawun al-arabi) -- made up of Jordan, Iraq, Egypt and North Yemen (later unified Yemen). The formation of the ACC was motivated by several factors, among these the need to deepen economic relations with Egypt and Iraq, and to band together four economically indebted states as a kind of collective lobby group for aid from the Gulf states.(8) While the ACC had motivations in domestic politics and strategic concerns, in other words, it was also seen by the Jordanian regime as one more step toward political and economic restructuring for the kingdom's long-term survival.(9) Within months of the formation of the new political-economic alignment, the regime implemented its austerity program with unexpectedly violent results.

The public response to the austerity measures and the resultant price hikes was swift and dramatic. Prices rose sharply for such goods as fuel, hard and soft beverages, and cigarettes. Rioting began in the town of Maan, in the south, resulting in police intervention. At least 17 people were injured in the melee that ensued.(10) The high level of public anger, however, was not aimed just at the latest government economic austerity policies. Rather, the austerity program might better be seen as the final straw for many Jordanians. Public discontent focused on broader and more endemic issues such as long-term political and economic mismanagement. Even before the 1989 riots, the person and government of Prime Minister Zayd al-Rifaai had come to be associated in the public mind with cronyism and corruption. And it was Rifaai who would bear the brunt of public anger once the unrest began. For many years after the 1989 riots, Rifaai -- whose father and grandfather had, like him, served many times each as prime minister -- had still not returned to any cabinet post, much less to the prime ministry. (He did, however, receive a royal appointment to Jordan's upper house of parliament following the 1997 elections).

Although the austerity plan triggered riots in many parts of Jordan, some good can be said to have come of the otherwise negative events. Specifically, the widespread social unrest provided the main impetus for substantive and even rapid movement in the long-discussed political liberalization process. Since at least 1984 the government had promised much but delivered little. In a sign of just how shaken the regime was by the April riots, the government was sacked and new elections were announced for November that same year. These were the first full parliamentary elections in Jordan in more than 20 years. Although political parties would not be legalized until 1993, previously underground leftist and nationalist parties began to reemerge into Jordanian public life, and many secular and even more Islamist opposition figures were elected to the lower house of the Jordanian parliament in November 1989.(11)

In the years that followed, the government relaxed restrictions on the media, lifted martial law, allowed for the legalization of political parties, and continued the process of parliamentary elections in 1993 and later in 1997. In sum, despite the social and political damage wrought by 
the IMF program and the riots that followed, Jordan also entered a new era in its political life with a riot-induced process of limited democratization.

\section{ECONOMIC ADJUSTMENT, 1996}

In August 1996, the Jordanian government implemented its second major economic adjustment program, again in cooperation with the IMF. The motivation this time around was not as dire as that surrounding the 1989 austerity measures. Rather, the new round of economic changes amounted simply to the second phase of the original program. Much had occurred in the years between 1989 and 1996. From 1989 to 1991, the kingdom had reeled under economic hardship, domestic unrest, and a regional crisis in which Jordan's attempt at a middle ground had lost it the economic support of the Gulf states and its Western allies. But in the second three-year period, 1992-94, the kingdom had realigned just as dramatically, stabilizing its economic situation, abandoning its political alignment with Iraq (and permitting Iraqi opposition to organize in Jordan), achieving rapprochement with the United States and even most Gulf states, and signing the peace treaty with Israel.(12)

Having recovered from the domestic and regional crises that marked the beginning of the decade and having consolidated its key international political and economic relationships, the regime turned again toward domestic economic adjustment. The Jordanian government had, in effect, agreed to sign on as an enthusiastic participant in the post-Cold War and post-Gulf War "New World Order," which appeared to be predicated on at least nominal political liberalization and also on more significant levels of economic liberalization. In its attempts to streamline its budget and bring its deficit more completely under control, the Jordanian government chose to focus once again on the bane of the IMF and other international creditors: domestic subsidies. The decision to target the bread subsidy in particular was also influenced by the abrupt rise in international wheat prices in 1995 from $\$ 175$ to $\$ 280$ per ton.(13)

Since the 1996 program emerged in a less constrained economic atmosphere than the earlier round of adjustments, it is particularly noteworthy that the public response so closely resembled that of 1989, with riots in the streets and calls for the government's resignation. This is perhaps still more intriguing when one considers that, unlike the abrupt austerity measures of 1989, the 1996 version appeared to approach in slow motion. National attention had been focused on impending new economic austerity measures for weeks before they were actually implemented. The economic adjustment program had, in fact, been the main focus of media attention and parliamentary debates. Indeed, the prime minister himself had made a point of holding a news conference as early as July 11,1996 , to explain his policy decisions and allay public fears. 
The message of the news conference, however, appeared to change as it wore on. At first, Prime Minister Kabariti seemed to indicate that no changes at all were to occur:

The government will not lift the subsidy given to Jordanian citizens. The

government will not lift the subsidy to the Jordanian citizens as long as I

have the honor of being in charge. I stress to you that this subsidy will

not be affected at all and that citizens will not bear any additional

burden to obtain their daily bread.(14)

At first, this seemed to indicate that the government had abandoned its plan to lift the subsidy; however, Kabariti was carefully allowing for the subsidy to be removed, so long as it was not "affected" and so long as Jordanians were in some way compensated. In response to a reporter's question, the prime minister modified his point to say that "there will be no lifting of the bread subsidy without supporting the citizens in return for this decision." And still later, he stated that "there will be a lifting of the bread subsidy, and the citizen will be paid the difference in prices, and this difference will exceed the increase in prices."(15) The press conference itself reflected the careful approach that the government attempted to take, by shifting even in its own use of language from outright denials that there would be any change, to vague allusions to minor levels of change, to stressing that, yes, there would be a change, but citizens would be amply compensated for it.

The government, in short, did indeed have every intention of doing away with the subsidy, but it also had a plan to soften the blow on the Jordanian public. Prime Minister Kabariti attempted to make the compensation plan as clear as possible:

Let me explain the mechanism. We will pay the difference in the price of

bread to all civil servants, the Armed Forces and the government, through a cost-of-living allowance. This will become part of the state budget. There will be legislation to show that there is a cost-of-living allowance equivalent to the percentage we will pay to the citizen: 1.28 Jordanian dinars for each member of the family regardless of age. Those who do not work in the public sector and the Armed Forces and those who have ration cards will be paid through the Supply Ministry or the Jordanian Banks.(16) 
He added that any who did not have ration cards would be able to apply for them and that the government had no intention of excluding Palestinians in the various refugee camps in Jordan. The very fact that the government bothered to hold a press conference at all reflected the changes in Jordan's political liberalization process since the previous economic crisis.

What was perhaps the most striking part of the news conference, however, was not the banter between the prime minister and reporters, but rather the personal intervention of King Hussein. While Kabariti was speaking, the king entered the room and literally as well as symbolically stood behind his prime minister. The king later made clear his support for Kabariti's economic reform efforts, even referring directly to the 1989 riots and appealing for public cooperation with the economic adjustment process in order to avoid a repeat of the earlier unrest. In an equally important substantive and symbolic move, the king also made a point of paying a high-profile visit to the headquarters of the Jordanian armed forces to discuss the same issue and make clear his support for the government's decisions.(17)

While the government did attempt to provide ample warning of its impending economic changes and even some level of compensation, the real effects on ordinary Jordanians were nonetheless severe. Compensation or not, the fact remained that bread prices more than doubled, and people feared that when prices stabilized they might amount to as much as a 300-percent increase. The compensation program itself was also problematic, since the approximately $\$ 1.80$ per-Jordanian per-month allowance was essentially offset by similar increases in the prices of dairy products. Wheat prices, in short, had affected not only bread, but also animal fodder and thus indirectly dairy prices as well.(18)

Before the implementation of the economic adjustment program, parliament took up the issue of the bread and fodder subsidies in its special summer session. The opposition bloc of 23 Islamist deputies, 16 of whom were members of the Islamic Action Front (IAF), strongly opposed the government's plan to lift the subsidy and decided to boycott parliamentary sessions that the prime minister was to attend. In their absence, Prime Minister Kabariti railed against them, referring to the boycott itself as a form of "corruption."(19) The Islamists, in turn, condemned the government as incompetent and unresponsive to parliament and called for the prime minister to resign. But ultimately the IAF boycott tactic failed. The Islamists had intended to deny the prime minister the needed quorum for any parliamentary votes, but the voting proceeded without the IAF deputies and their allies. In the subsequent motion against the government's price hikes on bread and fodder, only 23 of 52 deputies voted for the alternative proposal offered by parliament's own committee. Ironically perhaps, if the IAF deputies had shown up, their additional 23 votes would have reversed the vote outcome.(20) 


\section{DEJA VU? THE PUBLIC RESPONSE, 1996}

Within a few days of the implementation of the new adjustment program, Jordanians began to feel the effects of the price increases. With the lifting of the subsidy, the cost of bread had more than doubled. Again people took to the streets and again the riots began in areas that were not hotbeds of Palestinian nationalist or Jordanian Islamist activity (the two traditional foci of opposition in Jordan). Rather, as with the 1989 riots, the violence began in towns in the south of Jordan that have long been viewed as strongholds of support for King Hussein and his regime. The demonstrations began in Kerak but soon spread to Mean and Tafila, and later even to the downtown market area of Amman itself. In Kerak, demonstrations turned violent as police intervened. The vision of demonstrators and riot police clashing invoked for many Jordanians the imagery of the intifada in the occupied territories, complete with stones flying in one direction and tear gas canisters in the other. Indeed, for many Jordanians, the king's televised speech threatening to use an "iron fist" to put down "sedition" also recalled the intifada.(21) The government soon called in the regular army, and armored vehicles began to roll down the streets of Kerak as the army imposed a curfew on the city. Before the unrest came to an end, the rioters had turned their anger on targets that seemed to reflect public hostility toward economic privation and government power. The damages here were not to individuals but to property. The demonstrators set fire to several government offices, a private bank and numerous cars.(22)

In sum, the public response to economic austerity was strikingly similar in 1989 and in 1996 . But although the implementation of the IMF-sponsored adjustment program in 1996 resembles the events of 1989, the broader economic circumstances were still significantly different. The macroeconomic indicators in 1989, as discussed above, showed that Jordan's debt was twice its GDP and its budget and balance of payments deficits were virtually out of control. By 1996, however, these economic figures had been trimmed down considerably; the kingdom's macroeconomic picture showed a fairly clean bill of health.

Why, then, did the new program elicit similar levels of hostility and violence on the part of the public? One key reason may be found still within the context of the aggregate economic indicators themselves -- not for what they say, but for what they do not say. For although Jordan's economic statistics were far more robust in 1996 than they had been in 1989, they do not reveal that the reduced budget deficit had resulted in part from reduced government spending in specific areas. But this meant in practical terms that public-sector salaries had not increased significantly and that they had certainly not kept up with the cost of living. In addition, the tightened government budget had resulted in fewer available public-sector jobs. Following its first IMF adjustment program, the kingdom had managed to appeal to more foreign investors, again padding the economic statistics. But the fact remained that many of the visible effects of 
increased investment remained confined to middle-class and upscale neighborhoods in Amman and were certainly not felt in towns in the south like Kerak, Maan and Tafila.

Just as the economy appeared to be looking up, according to the aggregate statistics, many Jordanians found -- often for the first time -- that they had to commute to the capital to find work. And since the Gulf War, the usual external safety valves such as labor migration to the Gulf or jobs in export industries connected to Iraq were largely cut off. Nor had the peace treaty with Israel made up for these losses. The peace had been marketed to the public as the source of a coming investment and trade boon, but the real results were minimal and, again, restricted largely to the capital.(23) It is not a coincidence, therefore, that the riots occurred in places largely left out of Jordan's improving economic fortunes.

\section{THE GOVERNMENT RESPONSE, 1996}

In response to the political upheaval, the government dispatched security forces immediately, clashing with demonstrators. By the time the regular army moved in and the demonstrations had been brought under control, numerous arrests had been made. The government claimed that only 120 people were detained, while Kerak residents interviewed by Western reporters put the number at closer to 500 for their city alone. King Hussein went on television threatening to use an "iron fist" and any other means necessary to restore order.(24) The king also made a veiled threat regarding broader penalties in terms of the political liberalization process itself, by describing himself as uneasy over the state of Jordanian "democracy" and suggesting that it was being used by subversives as a shield for their activities.(25)

But in addition to resorting to outright coercion, the king also attempted to appease public frustration by traveling immediately to each of the cities involved in the riots. In Kerak, the king was greeted with chants of "Long live the king, and down with Kabariti!" reflecting -- as in the earlier riots -- public wrath at the head of government, but not at the head of state. Just as Prime Minister Rifaai was blamed for the economic hardship in 1989, Prime Minister Kabariti bore the brunt of public anger in 1996.(26) This is not to say that none of the anger was reserved for the king. Far from it, but at least at the public level -- and in the king's presence -- it was the prime minister who was the target. To some extent, the king enjoyed greater political legitimacy in 1996 than he had in 1989, still drawing in part on his popular stance during the Gulf War and the opening of the political system to limited amounts of democratization. But none of the economic and political changes of the 1990s had panned out to meet the full expectations of the public. Thus one should not underestimate the level of public dissatisfaction with the unfulfilled promise of economic change, political liberalization and peace. 
Still, from street demonstrators to members of parliament, calls abounded for the prime minister's resignation. But unlike the 1989 riots, this prime minister was not immediately sacked. To the contrary, Kabariti vociferously defended his economic policies as necessary medicine for the Jordanian economy and steadfastly refused to resign. Unlike Zayd al-Rifaai, Kabariti found himself publicly defended by the king himself. The king stated his support not only for the prime minister, but also for his economic policies, suggesting that the previous years of bread subsidies had been "a mistake."(27)

As the government and the monarchy closed ranks, the king, prime minister and other government officials also made it a point to focus the blame on outside agitators, internal subversives with foreign ties, and even on Saddam Hussein himself. The king suggested on television that pro-Iraqi Jordanians were at work. Similarly, Prime Minister Kabariti argued that "the Iraq Baath party was somehow very much involved in fomenting the riot that started in Kerak." And another government official noted that "it is no secret that President Saddam Hussein would like to undermine Jordan's stability and that Iraq has many supporters in Jordan waiting for the right moment to move."(28) The government thus charged that these subversives had indeed made their move. During a special meeting with members of parliament, the king continued the theme of local elements with foreign ties in which he disparaged the "old schools of the 1950s." In fleshing out this apparent allusion to Pan-Arab nationalist intrigues, the king added that "one cannot be a good citizen if he or she lacks a sense of national belonging."(29) Lower-level government officials would take that point further, suggesting that the rioters were simply acting "anti-Jordanian."(30)

The government's focus then shifted, perhaps inevitably, to the Jordanian Arab Socialist Baath party, the pro-Iraqi version of that party in Jordan, which had won one of the 80 seats in the 1993 parliamentary elections. The party's member of parliament, Khalil Haddadin, denied any involvement by the party but noted that many Baath party members were detained by security forces.(31) In interviews with the press, party spokesperson Ahmad al-Najdawi noted the ideological affinity between the Jordanian and Iraqi Baath parties, but strongly denied any political connections to Baghdad and any role in fomenting the bread riots.(32)

But the Baath was not the only group that found itself to be the target of the government sweep. According to at least one analyst, the majority of detainees were leftists and nationalists of various types. Surprisingly, another source of opposition was treated almost benignly in the government crack-down: the Islamists. In his televised speech, the king had even suggested that the Islamist opposition had behaved responsibly, unlike the allegedly pro-Iraqi and/or leftist demonstrators. Yet the Islamists had been among the regime's most vocal opponents before the bread subsidy was even lifted, and they would soon prove themselves to be less than pliant in the upheaval that followed.(33) Despite what may have been an attempt on the part of the regime to split the opposition between secular left and religious right, both wings of the 
parliamentary opposition banded together to demand the return of the bread subsidy and the resignation of the Kabariti government.

The government, however, pushed forward even months after the riots with its accusations of external links to Jordanian parties and, significantly, focused on the main secular leftist parties: the Jordanian Arab Socialist Baath party, the Progressive Arab Baath party, the Democratic Popular Unity party, and the People's Democratic party (better known as Hashd). Specifically, the government accused each of the four parties of violating the Political Parties Law, which prohibits parties from maintaining foreign links and from receiving funding from abroad.(34) The government followed through with its accusations by bringing law suits against each of them, the four main secular-left parties in the 11-party opposition bloc in the parliament. The bloc itself was led by the Islamic Action Front, but the IAF was essentially excluded from the government's criticism and from legal charges. Yet the opposition front essentially held together, and in the wake of the August 1996 riots Islamists, leftists and pan-Arab nationalists continued to call for the resignation of the government.

Rather than acceding to parliamentary opposition demands for the sacking of the government, the king instead dissolved the current session of parliament, thereby denying the opposition the parliamentary floor as a forum for criticizing the government. Thus unlike Rifaai, Kabariti did manage to hang on for many months after the 1996 crisis. But by 1997 he may have become too much of liability for the government to get anything done, and the king eventually replaced him with the same man that he had succeeded: Abd al-Salam al-Majali. Mr. Majali, however, soon found that he too would have considerable difficulty dealing with an increasingly recalcitrant parliamentary opposition. Yet the economic adjustment program remained in place.

\section{CONCLUSIONS}

The comparison between the IMF riots of 1989 and 1996 shows that although the economic plans were similar and public hostility and the riots themselves were virtually identical, nonetheless the state's reactions varied considerably. In 1989 the king had made a point of being out of the country when the IMF austerity measures were implemented, only to return to severe social unrest. The king's distance from the events, calculated or not, allowed the monarchy as well as the public to place the blame on bungling by the Rifaai government. But the monarchy had been clearly and deeply shaken by the depth of public anger and quickly made a series of concessions: sacking the prime minister, reshuffling the cabinet, and perhaps most important, calling new elections for the first time in more than 20 years. In 1996, in contrast, the regime maintained its support for the prime minister and his government as well as 
its "iron fist" policy in putting down the riots. In addition, the monarchy made repeated charges of external subversion and internal sedition, with particular focus on secular leftist political parties. In the 1989 riots, these parties still operated underground. But in 1996, as legal parties, many with seats in parliament, they found themselves the targets of government law suits over alleged illegal "foreign links."

In 1989, at least some good came of the political explosion, since it was the catalyst for more genuine attempts at liberalization and democratization. But in 1996, even though the regime managed to weather the political unrest, serious questions remained. For the government stayed its course on economic adjustment, despite public and parliamentary opposition. Jordan's more open and dynamic press in many cases criticized the government considerably in 1996, in contrast to the wholesale subservience of the Jordanian media in the earlier crisis. Yet the very openness and depth of the stinging criticisms of government policy -- regarding economic austerity and also relations with Israel -- proved too hard-hitting for the monarchy, which by the late summer of 1997 had pushed through a series of measures to stifle media criticism through elastic and vague rules about "national security" matters. For the most part, however, the regime appeared to see the crisis as over by the fall of 1996 . But here lies the main disconnect between the regime and the people. For many in the public saw the riots as symptomatic not only of economic concerns, but also of something bigger.

Jordan had, between 1989 and 1996, realigned its international position considerably. The regime that had won so much public support for its stance during the Gulf War had now become a sharp critic of the Saddam Hussein regime, allowing Iraqi opposition groups and even highranking exiles refuge in the kingdom. In addition, Jordan had mended all fences with the West, achieved rapprochement with most Gulf monarchies, and concluded a full peace treaty with Israel. Jordan, in short, had realigned itself wholesale. toward Western and pro-Western states and had; in effect, signed on as an enthusiastic participant in the neoliberal world order. Its acceptance of the norms of this new world order -- some level of political liberalization, free markets, privatization, and economic adjustment -- earned it the praise and support of the world's key financial institutions (and Jordan's main creditors) from the IMF to the Paris Club.

From the government's perspective, this realignment was entirely successful. But for many in Jordanian society, the regime's policies too often sounded like a sellout. Just as many at the top of the regime felt more comfortable and secure than ever, the riots should have provided another wake-up call to the effect that the rest of the country did not share this optimistic view. The disconnect becomes clearer if we consider that regime officials appear to believe that economic adjustment is non-negotiable and that political liberalization has essentially run its course; whereas many outside of government see economic adjustment as having gone too far already and political liberalization as only just beginning. This difference in views of the past, present and future of the kingdom was reflected in the 1996 riots, but it is important to note that 
this is not over. Indeed, the opposition boycott of the November 1997 elections suggested that the disconnect continues. And the later 1998 riots in Maan over Jordan's role in yet another U.S.-Iraqi crisis only underscored the deeper tensions within the kingdom.

The precariousness of state-society relations within Jordan is rendered all the more salient given the continuing illness of King Hussein and the looming prospect of political succession within the kingdom. Veteran observers of Jordanian politics might reasonably note, of course, that both the king and indeed the country itself can be considered among the great "survivors" of Middle East politics. That is undoubtedly true. It is also true that nothing lasts forever. The key issue today, therefore, is simply to recognize the nature of the challenges facing Jordan at the turn of the century. The regime and its opposition clearly have different views of Jordan's needs. But the 1996 riots were symptomatic of anger and resentment over far more than the price of bread.(35) It is difficult, in fact, to overestimate the depth of disillusionment within Jordan regarding the economy, the political liberalization process, and peace with Israel. If the Hashemite regime assumes that the "bread riots" were only about bread, it may do so at its own peril.

\section{Footnotes}

(1) For an analysis of economic adjustment and political stability more generally, see Henry S. Bienen and Mark Gersovitz, "Economic Stabilization, Conditionality, and Political Stability," International Organization 39 (4) 1985: 729-754.

(2) On Jordan's economy and government policies, past and present, see the excellent collection of essays assembled by Jordan's Center for Strategic Studies: Mustafa Hamarnah, ed., "Al-Igtisad al-Urduni: al-Mushkilat wa al-Ifag," (The Jordanian Economy: Problems and Horizons) Amman: Center for Strategic Studies, 1994.

(3) On Jordan's later (1994) decision to conclude just such a treaty between Israel and Jordan, see Curtis R. Ryan, "Jordan in the Middle East Peace Process: From War to Peace with Israel," in Ilan Peleg, ed., The Middle East Peace Process: Interdisciplinary Perspectives (Albany: State University of New York Press, 1998).

(4) Interviews with Dr. Jawad al-Anani, former Jordanian minister of industry and trade, of labor and of supply (Amman, 10 April 1993) and with economic advisers to the prime minister (Amman, April 7, 1993). More recently Dr. Anani served as deputy prime minister of Jordan and remains a major figure in Jordanian economic planning. In 1998, when Fayiz Tarawnah became Jordan's new prime minister, Dr. Anani became chief of the Royal Hashemite Court. 
(5) Interview with Zayd al-Rifaai (Amman, March 29, 1993).

(6) Economist Intelligence Unit, Jordan: Country Report, no. 2, 1989: pp. 10-11.

(7) Interviews with Jordanian foreign ministry and former cabinet officials (Amman, March 1993).

(8) Mohammad Wahby, "The Arab Cooperation Council and the Arab Political Order," American-Arab Affairs 28 (1989): 66; Laurie A. Brand, Jordan's Inter-Arab Relations: The Political Economy of Alliance Making (New York: Columbia University Press, 1994), pp. 230 and 235 .

(9) See Curtis R. Ryan, "Jordan and the Rise and Fall of the Arab Cooperation Council," The Middle East Journal 52 (3) Summer 1998: pp. 386-401.

(10) Economist Intelligence Unit, Jordan: Country Report, no. 2, 1989: p. 5.

(11) The opposition parliamentarians included 22 members of the Muslim Brotherhood, 12 independent Islamists, and ten Pan-Arab nationalists and leftists (including three Baathists, one communist, and two deputies linked to leftist organizations of the PLO). Economist Intelligence Unit, Jordan: Country Report, no. 2, 1990: p. 7.

(12) Significantly, in the midst of the August power struggle between the government and Islamist-led opposition in parliament, Prime Minister Kabariti held a summit meeting in Jiddah, Saudi Arabia, to enhance economic links between the two countries. Al-Raay 14 August 1996, p. 1, in Foreign Broadcast and Information Service -- Near East Service (hereafter cited as FBISNES-96-159).

(13) Sana Kamal, "Jordan: Bread Subsidy to Go," Middle East International, August 2, 1996, p. 11.

(14) News conference by Jordanian Prime Minister Abd-al-Karim al-Kabariti, Amman Radio Jordan Network 1157 GMT, July 11, 1996, in the FBIS-NES-96-135.

(15) Ibid.

(16) Ibid.

(17) Kamal, "Jordan: Bread Subsidy to Go," p. 11.

(18) Sana Kamal, "Jordan: The Price of Bread," Middle East International, Sept 6, 1996: pp. 1314.

(19) Jordan Times, August 15-16, 1996, p. 1, in FBIS-NES-96-159.

(20) Jordan Times, August 15-16, 1996, p. 1, in FBIS-NES-96-159. 
(21) Author's interviews with Jordanian journalists (Amman, May 1997).

(22) Jamal Halaby, "More Jordanians Riot in Bread Price Protest," The Washington Post, August $18,1996$.

(23) Pamela Dougherty, "Les emeutes du pain a Kerak: une reponse au programme d'ajustement structurel en cours en Jordanie (un apercu general)/The pain of adjustment: Kerak's bread riots as a response to Jordan's continuing economic restructuring program: a general overview," Jordanies, no. 2, 12, 1996, pp. 95-99.

(24) Jamal Halaby, "More Jordanians Riot in Bread Price Protest," The Washington Post, August 19, 1996.

(25) Gellman, "Bread-Price Riots Pose Challenge."

(26) Halaby, "More Jordanians Riot."

(27) Gellman, "Bread-Price Riots Pose Challenge."

(28) Quoted in Jack Redden, "Detentions Follow Riots in Jordan," The Washington Post, August 20, 1996.

(29) Kamal, "Jordan: The Price of Bread." p. 14.

(30) Author's interviews in Amman, May 1997.

(31) Redden, "Detentions Follow Riots in Jordan."

(32) "Arab Socialist Baath Party Denies Accusations," The Star (Amman), August 22, 1996.

(33) Kamal, "Jordan: The Price of Bread."

(34) "Government Gets Ready to Hunt Down Parties with `Foreign Links," The Star (Amman), December 5, 1996.

(35) Note, for example, the comment by Kerak Mayor Ahmad Mahadin during the 1996 crisis: "If the government continues its iron fist policies, there will be an explosion a thousand times more powerful than the one that already took place." Quoted in Reddin, "Detentions Follow Riots in Jordan." 